\section{Interdependence between banking earnings, banking security and growth achievement: case study in the ASEAN community}

Banking profit, security and economic growth

\author{
Minh Phu Pham
}

Central Institute for Economic Management, Hanoi city, Vietnam
Received 3 February 2020 Revised 28 March 2020 Accepted 29 March 2020

\begin{abstract}
Purpose - The main purpose of this paper is to examine the existence of interdependence amongst banking earnings, banking security and growth performance across the Association of Southeast Asian Nations (ASEAN) region.

Design/methodology/approach - This paper utilizes a panel autoregressive distributed lag method with the annual data of nine ASEAN members over 1996-2017.

Findings - Only the short-run Granger causal impact of banking profitability on economic expansion is supported, while the long-run Granger causality between all the variables is strongly recognized. Increased banking well-being supports economic development, while higher banking security might have inverse impacts. However, increasing the banking profit without the corresponding better soundness can be detrimental to the economic growth in the short run and much more in the long run. Thus, improving banking profitability and stability simultaneously has positive net effects on the economic development.

Research limitations/implications - This research is restricted to unavailable data and limited measurements of both banking profitability and stability. Further inclusion of other macro-economic variables, other banking development aspects or even non-banking indicators should also be considered.

Practical implications - National governments should emphasize a convenient financial environment, which can strongly enhance the positive relationship between banking earnings, banking safeness and output growth. Also, the relevant policies on higher banking well-being and stricter security obligations have to be simultaneously maintained.

Originality/value - Few papers have inspected the interrelationship between banking stability, banking profitability and economic growth, particularly in the ASEAN region. This causes the banking literature shortage, as well as insufficient insights for the financial policymakers into their endogenous dynamics. Thus, the study is the first attempt to fulfil the research gap.
\end{abstract}

Keywords Banking earnings, Banking security, Economic achievement, Granger-causality

Paper type Research paper

\section{Introduction}

The banking sector development, especially the dynamics of banking profitability and stability, is closely associated with growth performance across countries. The empirical economic growth literature shows that an insufficiently supervised banking system might cause the financial crisis with potentially devastating effects. By contrast, an efficient and profitable one provides better financial services, allowing an economy to increase its potential growth (Pradhan et al., 2014).

The Association of Southeast Asian Nations (ASEAN) region is no exception. The East Asia community has witnessed the homogeneous banking development for at least two

(C) Minh Phu Pham. Published in Journal of Economics and Development. Published by Emerald Publishing Limited. This article is published under the Creative Commons Attribution (CC BY 4.0) license. Anyone may reproduce, distribute, translate and create derivative works of this article (for both commercial and non-commercial purposes), subject to full attribution to the original publication and authors. The full terms of this license may be seen at http://creativecommons.org/licences/by/4.0/ legalcode.

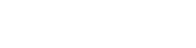


JED

22,2

reasons. Firstly, the commercial banks are predominant sources of financial assets, holding over $80 \%$ of the region's financial assets. Secondly, the banking sector enhancement has been supported by the national governments to ensure the banking industry security (Banna et al., 2019). This entails the crucial position of the banking sector in the growth achievement, particularly across the ASEAN area. Consequently, such studies to ease the constraints of understanding co-integration and causality between banking safeness, banking earnings and economic improvement are necessary, especially from an economic policy perspective.

The causality determination between financial advancement and economic attainment has escalated recently. Economists and researchers have traced the fundamental theoretical discussion to Hammond (1991) and Schumpeter (1982) favouring the hypothesis that financial development pushes up economic expansion. On the contrary, Robinson (1952) and Hicks (1969) posit that, by and large, growth leads and finance follows. Furthermore, Lewis (1955) and Patrick (1966) postulate a feedback relationship between financial growth and economic development.

Following the theoretical discussion, the empirical analysis on the causality between banking development and economic growth has attracted attention in the banking literature. Particularly, Habibullah and Eng (2006) examined the interaction between financial development and economic growth in Asian developing countries. Recently, Jayakumar et al. (2018) and Nucu and Anton (2019) have continued contributing to the banking literature by investigating the interdependence between banking competitiveness, banking security and growth progress in the Central and Eastern European regions. In broad-spectrum, the empirical results have recognized the significant influence of banking improvement on growth expansion over different regions.

However, only a few researchers have investigated this relationship across the ASEAN region. Also, they have mainly emphasized the separate pairwise relationships and ignored the simultaneous causal interactions. First is the link between banking earnings and economic advancement (Kyophilavong et al., 2016 in Lao PDR); second is between banking stability and economic development (Wulandari and Kusairi, 2017 in Indonesia); and finally between banking stability and banking profitability (Khan et al, 2018 in ASEAN region and Oktaviyanti and Purnawan, 2019 in ASEAN-5). Although Pradhan et al. (2014) and Pradhan et al. (2017) have already started inspecting the causal interactions between banking performance and economic growth in the ASEAN region, they have only taken the banking depth into account. The interrelations between banking profitability, stability and output development remain unclear.

Thus, this paper aims to fill this literature gap. Furthermore, this study is also motivated with a practical perspective. One of the main targets of financial regulators is to ensure banking stability to support sustainable economic growth. Therefore, this study is supposed to provide credible evidence about various aspects in which one can rationalize the dynamic interactions between banking profitability, stability and economic improvement. This is necessary empirical evidence to build up the comprehensive financial policy systems.

The research question is relevant to the existence of an interrelationship between banking security, banking earnings and economic advancement. Therefore, the proposed hypotheses will include (1) banking earnings Granger - causes growth expansion and vice versa; (2) banking earnings Granger - causes banking security and vice versa (3) banking security Granger - causes growth expansion and vice versa.

Annual panel data of nine ASEAN countries are employed over 1996-2017. The panel vector-error correction framework is amongst the appropriate approaches to investigate the dynamic interaction amongst the variables. Accordingly, we can treat our variables as endogenous and then examine both short- and long-term Granger-causal impacts of one variable on others. However, the models are meaningful only if all the variables have the same order of integration and are co-integrated. Otherwise, the panel autoregressive distributed lag method is preferred, which can address the co-integration progress for a long-term 
relationship, regardless the covariates are $I(0), I(1)$ or a mix of both. Thus, the tests for panel unit root and panel co-integration are necessary to choose the appropriate method.

The empirical results only indicate the significant short-term Granger-causal effect of banking profitability on economic growth. However, we strongly support the long-run Granger-causality amongst the variables. Additionally, the increased banking profitability positively influence the economic growth, while the increased banking stability might deteriorate the economic expansion in some circumstances. However, boosting the banking well-being without the corresponding higher soundness can erode the economic development in the short term and much more in the long term because of the potential non-performing loans. Thus, the higher banking profitability and stricter banking safeness regulation have to be maintained simultaneously.

The remaining of the study will proceed as follows. Firstly, some previous empirical papers and rationale for the analysis are discussed in detail in Section 2. Detailed variables and data will be presented in Section 3. Subsequently, method and identification strategy are in Section 4, while the main outcomes are in Section 5. Lastly, the conclusion and policy recommendation are drawn out.

\section{Literature review and the proposed hypotheses}

The casual inter-correlation between banking development and economic spread has already been inspected quantitatively for different regions. The summaries of the studies are shown below.

Firstly, using panel vector autoregression, Habibullah and Eng (2006) inspected the causal relationship between financial development and economic growth across the 13 Asian developing countries including Bangladesh, India, Indonesia, South Korea, Lao PDR, Malaysia, Myanmar, Nepal, Pakistan, Philippine, Singapore, Sri Lanka and Thailand over 1990-1998. The economic growth was measured by the real gross domestic product (GDP) per capita, while the financial development was proxied by the ratio of domestic credit to GDP. The authors argued that financial development already promotes economic output. These results supported Patrick's supply-leading hypothesis.

Next, Jayakumar et al. (2018) also investigated the casual interdependence between banking competition, banking stability and economic growth across 32 European countries over 1996-2014. However, being different from Habibullah and Eng (2006), the authors instead employed a panel vector-error correction model. The economic growth was measured by the real GDP per capita. The banking competition was proxied by Lerner index, Boone index, H-statistic, bank concentration index and foreign ownership, while the stability is by bank capitalization, $Z$-score, non-performing loans, provision of non-performing loans, the ratio of private credit to deposit and a composite safeness index. They confirmed unidirectional or bidirectional, or eventually no short-run causal links between the variables in some cases. However, both banking competition and stability were the key drivers of economic growth in European nations in the long run.

Subsequently, Nucu and Anton (2019) also analysed the causal interdependence between banking competitiveness, banking safeness and growth development across the eleven Central and Eastern European nations over 2000-2015 using the panel vector-error correlation model. The economic advance was assessed by the real GDP per capita. The stability indicators included Z-score, non-performing loans, capitalization and private credit to deposit to GDP, while the competitiveness contained Lerner index, Boone indicator and bank concentration. Similar to Jayakumar et al. (2018), the authors strongly recognized the Granger-causal impact of economic performance on banking stability and vice versa. However, the Granger-causality between banking competitiveness and economic expansion was mixed and eventually, in some cases, no causality was proven.
Banking profit, security and economic growth 
JED

22,2

The earlier studies support the Granger-causality between the banking and economic progress across European and Asian communities. However, as far as we know, few papers have inspected the interrelationship in the ASEAN, particularly between banking stability, banking profitability and economic growth. Only Pradhan et al. (2014) and Pradhan et al. (2017) already affirmed the Granger-connection between banking expansion and economic output in the ASEAN. However, the banking expansion was proxied by broad money supply, claims on private sectors or domestic credit provided by the banking sector, which might reflect the banking depth, but profitability or stability. Thus, the questions about the Granger - impacts of banking profit or stability on the economic output and vice versa remain unclear, especially in the ASEAN. The banking literature gap is, therefore, fulfilled in the study.

Subsequently, we will review the previous empirical research on the following relations: banking earnings and growth progress; banking stability and growth progress; and banking profitability and banking stability and then draw out the hypothesis examined in the paper. A quick recapitulation of three main flows of literature considered below is illustrated in Table 1. Generally, there are various outcomes for each particular country/region at different times.

The first strand of academic literature investigates the connection between banking profits and output growth. The results could be summarized under the following four hypotheses. Firstly, the demand-following hypothesis $\left(\mathrm{DFH}^{\mathrm{A}}\right)$ recognizes the larger economic development, the larger firms' loans and deposits supplied and subsequently the greater banking profit. The hypothesis is supported by Bolt et al. (2012) and Acaravci and Çalim (2013). Secondly, the supply-leading hypothesis $\left(\mathrm{SLH}^{\mathrm{A}}\right)$ represents increased banking earnings cause high output growth. This is because an efficient banking sector tends to use financial sources effectively, increasing the economy's productivity. The argument is supported in Anthony (2012) and Daly and Frikha (2016). Thirdly, the feedback hypothesis concludes banking earnings and growth explosion react to each other. The inference is confirmed by Miralles-Quiros et al. (2018). Finally, the neutrality hypothesis $\left(\mathrm{NEH}^{\mathrm{A}}\right)$ suggests banking profitability and economic development are independent. The hypothesis is supported by Chang (2002).

The second strand inspects the link between banking stability and banking profitability and the results are also summarized in the following four hypotheses. Firstly, the demandfollowing hypothesis $\left(\mathrm{DFH}^{\mathrm{B}}\right)$ indicates the banking profitability might cause stability. The more profitable, the higher efficiency in resource utilization, the more risks managed and subsequently the more secure the banks are. However, when a bank concentrates much on earnings, it is easier to ignore some financial security policies in providing credits and loans, leading to more risks. The arguments are encouraged in Ryoo (2013). Secondly, the supplyleading hypothesis $\left(\mathrm{SLH}^{\mathrm{B}}\right)$ recognizes banking stability is likely to cause profitability. The more stable the banking sector, the less the cost to manage risks, and then the more fruitful it is. However, over-regulating can hinder banking sectors to make a profit. The hypothesis is supported by Abel and Le Roux (2016) and Knezevic and Dobromirov (2016). Thirdly, the feedback hypothesis $\left(\mathrm{FBH}^{\mathrm{B}}\right)$ predicts banking safety and profitability enhance each other. The hypothesis is confirmed by Tagkalakis (2014) and I. Motelle and Biekpe (2014). Lastly, the neutrality hypothesis $\left(\mathrm{NEH}^{\mathrm{B}}\right)$ illustrates banking profitability and stability are independent, which is proved by Tan (2016).

Finally, the relation between banking stability and economic enhancement are also studied. The results are summarized in the four hypotheses. Firstly, the demand-following hypothesis $\left(\mathrm{DFH}^{\mathrm{C}}\right)$ postulates the increased economic prosperity will generate banking stability. Stricter security regulations of loans provided under economic explosion increase the banking sector operation for default risk. The conclusion is supported by Trabelsi and Trad (2017), Alshubiri (2017), and Pedro et al. (2018). Secondly, the supply-leading hypothesis $\left(\mathrm{SLH}^{\mathrm{C}}\right)$ suggests the key entities are likely to control risks and default more effectively under a 


\begin{tabular}{|c|c|c|c|c|}
\hline Research & Research place & Period & $\begin{array}{l}\text { Hypothesis } \\
\text { confirmed }\end{array}$ & \multirow{3}{*}{$\begin{array}{r}\text { security and } \\
\text { economic } \\
\text { growth }\end{array}$} \\
\hline \multicolumn{4}{|c|}{ Strand 1: Relation between banking profit and output expansion } & \\
\hline Acaravci and Çalim (2013) & Turkish & $\begin{array}{l}1998- \\
2011\end{array}$ & $\mathrm{DFH}^{\mathrm{A}}$ & \\
\hline Bolt et al. (2012) & 17 OECD nations & $\begin{array}{l}1979- \\
2007\end{array}$ & $\mathrm{DFH}^{\mathrm{A}}$ & 253 \\
\hline Miralles-Quiros et al. (2018) & Brazil & $2002-$ & $\mathrm{FBH}^{\mathrm{A}}$ & \\
\hline Anthony (2012) & Nigeria & $\begin{array}{l}1970- \\
2006\end{array}$ & $\mathrm{SLH}^{\mathrm{A}}$ & \\
\hline Daly and Frikha (2016) & 10 countries & $\begin{array}{l}2005- \\
2012\end{array}$ & $\mathrm{SLH}^{\mathrm{A}}$ & \\
\hline Chang (2002) & Mainland China & $\begin{array}{l}1987- \\
1999\end{array}$ & $\mathrm{NEH}^{\mathrm{A}}$ & \\
\hline \multicolumn{5}{|c|}{ Strand 2: Relation between banking profit and banking security } \\
\hline Ryoo (2013) & - & - & $\mathrm{DFH}^{\mathrm{B}}$ & \\
\hline Motelle and Biekpe (2014) & Southern Africa & $\begin{array}{l}1984- \\
2010\end{array}$ & $\mathrm{FBH}^{\mathrm{B}}$ & \\
\hline Tagkalakis (2014) & 20 OECD nations & $\begin{array}{l}1997- \\
2010\end{array}$ & $\mathrm{FBH}^{\mathrm{B}}$ & \\
\hline Tan (2016) & China & $\begin{array}{l}2003- \\
2011\end{array}$ & $\mathrm{NEH}^{\mathrm{B}}$ & \\
\hline Abel and Le Roux (2016) & Zimbabwe & $\begin{array}{l}2009 \\
2014\end{array}$ & $\mathrm{SLH}^{\mathrm{B}}$ & \\
\hline $\begin{array}{l}\text { Knezevic and Dobromirov } \\
\text { (2016) }\end{array}$ & Serbia & $\begin{array}{l}2004- \\
2011\end{array}$ & $\mathrm{SLH}^{\mathrm{B}}$ & \\
\hline \multicolumn{5}{|c|}{ Strand 3: Relation between banking security and output expansion } \\
\hline Alshubiri (2017) & Oman & $\begin{array}{l}2008- \\
2014\end{array}$ & $\mathrm{DFH}^{\mathrm{C}}$ & \\
\hline Pedro et al. (2018) & $33 \mathrm{OECD}$ nations & $\begin{array}{l}1991- \\
2011\end{array}$ & $\mathrm{DFH}^{\mathrm{C}}$ & \\
\hline Trabelsi and Trad (2017) & Gulf and Southeast Asia & $\begin{array}{l}2006- \\
2013\end{array}$ & $\mathrm{DFH}^{\mathrm{C}}$ & \\
\hline Dell'ariccia et al. (2008) & 41 nations & $\begin{array}{l}1980- \\
2000\end{array}$ & $\mathrm{FBH}^{\mathrm{C}}$ & \\
\hline Fu et al. (2014) & 14 Asia Pacific countries & $\begin{array}{l}2003- \\
2010\end{array}$ & $\mathrm{NEH}^{\mathrm{C}}$ & \\
\hline Hoggarth et al. (2002) & $\begin{array}{l}\text { Developed and emerging-market } \\
\text { nations }\end{array}$ & $\begin{array}{l}1977- \\
1998\end{array}$ & $\mathrm{SLH}^{\mathrm{C}}$ & Table 1. \\
\hline Jayakumar et al. (2018) & 32 European nations & $\begin{array}{l}1996- \\
2014\end{array}$ & $\mathrm{SLH}^{\mathrm{C}}$ & $\begin{array}{l}\text { Recap of literature } \\
\text { review on pairwise } \\
\text { interaction amongst }\end{array}$ \\
\hline Jokipii and Monnin (2013) & 18 OECD nations & $\begin{array}{l}1980- \\
2007\end{array}$ & $\mathrm{SLH}^{\mathrm{C}}$ & $\begin{array}{l}\text { 1nteraction amongst } \\
\text { banking security, } \\
\text { banking profit and }\end{array}$ \\
\hline \multicolumn{4}{|c|}{ Source(s): Author's summary } & output \& \\
\hline
\end{tabular}

well-secured banking sector, which leads to more efficient resource utilization and subsequently greater economic productivity. By contrast, over-regulating the banking explosion probably deteriorates economic enhancement. The conclusion is encouraged by Hoggarth et al. (2002), Jokipii and Monnin (2013) and Jayakumar et al. (2018). Thirdly, the feedback hypothesis $\left(\mathrm{FBH}^{\mathrm{C}}\right)$ postulates banking security influences economic advancement and vice versa. The argument is promoted by Dell'ariccia et al. (2008). Finally, the neutrality hypothesis $\left(\mathrm{NEH}^{\mathrm{C}}\right)$ argues banking stability and economic growth are independent. Banking 
JED

22,2

254

security is strongly responsive to interest rate and investment, especially in the short-run. Hence, it might not identify its significant influence on economic development. The hypothesis is supported by Fu et al. (2014).

The main research gap in recent literature is an investigation of interdependence between all the variables of interest in the ASEAN region, especially given their dynamic integration over the years. This study plans to fulfil the research lack by examining their causal connections. Evidently, amongst other things, our study will meld the strands of the literature. We expect to test the three main hypotheses: Hypothesis A: Economic growth Granger - causes banking profit and vice versa; hypothesis B: banking profit Granger causes banking security and vice versa and hypothesis C: economic growth Granger causes banking security and vice versa. Figure 1 summarizes the proposed hypotheses, which demonstrates the direction of possible causality amongst these aforementioned variables.

Where $\mathrm{H}_{1}^{\mathrm{A}}{ }_{1}$ : Economic growth Granger - causes banking profitability, supporting the demand-following hypothesis $\left(\mathrm{DFH}^{\mathrm{A}}\right) ; \mathrm{H}_{2}^{\mathrm{A}}{ }_{2}$ : Banking profitability Granger - causes economic growth, supporting the supply-leading hypothesis $\left(\mathrm{SLH}^{\mathrm{A}}\right) ; \mathrm{H}^{\mathrm{A}}{ }_{3}$ : Banking profitability and economic growth boost each other, supporting the feedback hypothesis $\left(\mathrm{FBH}^{\mathrm{A}}\right) ; \mathrm{H}_{4}^{\mathrm{A}}$ : Banking profitability and economic are independent, supporting the neutrality hypothesis $\left(\mathrm{NEH}^{\mathrm{A}}\right) ; \mathrm{H}_{1}^{\mathrm{B}}$ : Banking profitability Granger - causes banking stability, supporting demandfollowing hypothesis $\left(\mathrm{DFH}^{\mathrm{B}}\right) ; \mathrm{H}^{\mathrm{B}}{ }_{2}$ : Banking stability Granger - causes banking profitability, supporting supply-leading hypothesis $\left(\mathrm{SLH}^{\mathrm{B}}\right) ; \mathrm{H}_{3}^{\mathrm{B}}$ : Banking stability and banking profitability boost each other, supporting feedback hypothesis $\left(\mathrm{FBH}^{\mathrm{B}}\right) ; \mathrm{H}^{\mathrm{B}}{ }_{4}$ : Banking stability and banking profitability are independent, supporting the neutrality hypothesis $\left(\mathrm{NEH}^{\mathrm{B}}\right) ; \mathrm{H}_{1}^{\mathrm{C}}$ : Economic growth Granger - causes banking security, supporting demandfollowing hypothesis $\left(\mathrm{DFH}^{\mathrm{C}}\right) ; \mathrm{H}_{2}^{\mathrm{C}}$ : Banking security Granger - causes economic growth, supporting supply-leading hypothesis $\left(\mathrm{SLH}^{\mathrm{C}}\right) ; \mathrm{H}_{3}^{\mathrm{C}}$ : Banking securities and growth explosion react to each other, supporting the feedback hypothesis $\left(\mathrm{FBH}^{\mathrm{C}}\right) ; \mathrm{H}_{4}^{\mathrm{C}}$ : Banking security and output growth are independent, supporting the neutrality hypothesis $\left(\mathrm{NEH}^{\mathrm{C}}\right)$.

\section{Data and variables}

Annual panel data are employed in the study over 1996-2017, which is mainly obtained from the World Bank. However, Laos PDR is excluded from the study because of much missing data over the period. Thus, the data only cover nine ASEAN members. Due to unavailable data from some ASEAN countries over the whole same duration, the panel data is unbalanced.

To gauge the interrelationship between the banking security (BSI), banking profitability (BPI) and economic expansion, we employ proxy variables for each dimension. All the variables are country level and expressed in percentage.

Firstly, the economic development (variable GRW) is evaluated by the growth of GDP per capita, consistently with Chang (2002), Habibullah and Eng (2006), Jayakumar et al. (2018)

Figure 1.

Expected hypothesis on the causal link between growth performance, banking security and banking profit

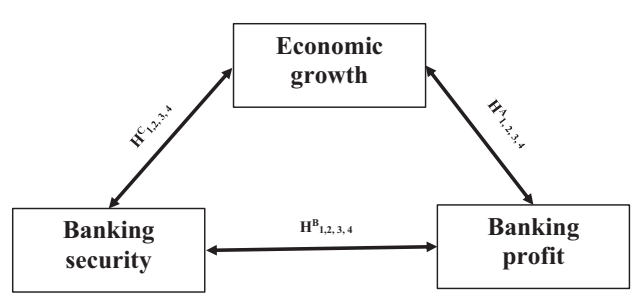


and Nucu and Anton (2019). Next, the banking security is expressed via three measures, namely, banking system $z$-scores (variable ZSC); private credit by the domestic deposit (variable CRE) and bank liquid assets to deposits and short-term funding (variable LIQ). These measures rely on relevant literature (Abel and Le Roux, 2016; Knezevic and Dobromirov, 2016; Tan, 2016). Finally, the banking profitability is also represented by three indicators, including returns on average assets (variable ROA); returns on average equity (variable ROE) and net interest margin (variable NIM), consistently with Bolt et al. (2012), Acaravci and Çalim (2013), Tagkalakis (2014), and Daly and Frikha (2016).

There is no single measurement to completely express the banking profitability characteristic. Each of the three individual measurements (ROA, ROE or NIM) is to represent one specific dimension of banking profitability. Thus, a composite index of banking profit (variable PROFIT) is expected to reflect the general dynamic of banking earnings in a specific nation. This index combines all the three indicators (ROA, ROE, NIM) and is generated by using the principal component analysis (PCA). The same interpretation is applied to the banking stability composite index, which consists of ZSC, CRE and LIQ using PCA (variable STABILITY). The statistical description of PCA is shown in Table A1, while those of the measurements are in Table A2.

\section{Method and identification strategy}

This paper attempts to examine the dynamic relationship between banking stability, banking profitability and economic growth. Thus, the panel vector-error correction framework is an appropriate approach utilized in Jayakumar et al. (2018) and Nucu and Anton (2019). Accordingly, using the VEC methodology, we can treat the variables of interests as endogenous and therefore examine the short- and long-run effects of banking profitability on stability and economic growth, and respectively, the reverse effects. Our model can be written as:

$$
\begin{aligned}
{\left[\begin{array}{c}
\Delta \mathrm{GRW}_{i t} \\
\Delta \mathrm{BPI}_{i t} \\
\Delta \mathrm{BSI}_{i t}
\end{array}\right]=} & {\left[\begin{array}{c}
\alpha_{1 i} \\
\alpha_{2 i} \\
\alpha_{3 i}
\end{array}\right]+\sum_{k=1}^{n}\left[\begin{array}{lll}
\beta_{11 i k} & \beta_{12 i k} & \beta_{13 i k} \\
\beta_{21 i k} & \beta_{22 i k} & \beta_{23 i k} \\
\beta_{31 i k} & \beta_{32 i k} & \beta_{33 i k}
\end{array}\right] *\left[\begin{array}{c}
\Delta \mathrm{GRW}_{i t-k} \\
\Delta \mathrm{BPI}_{i t-k} \\
\Delta \mathrm{BSI}_{i t-k}
\end{array}\right]+\left[\begin{array}{c}
\delta_{1 i} \mathrm{ECT}_{i t-1} \\
\delta_{2 i} \mathrm{ECT}_{i t-1} \\
\delta_{3 i} \mathrm{ECT}_{i t-1}
\end{array}\right] } \\
& +\left[\begin{array}{c}
\varepsilon_{1 i t} \\
\varepsilon_{2 i t} \\
\varepsilon_{3 i t}
\end{array}\right]
\end{aligned}
$$

where $i$ denotes individual ASEAN countries, $t$ denotes years over 1996-2017; $\Delta$ is the first different filter, in which $\Delta \mathrm{GRW}_{i t}$ captures economic growth; $\Delta \mathrm{BSI}_{i t}$ captures one of the banking stability indicators (ZSC, CRE, LIQ or STABILITY); $\triangle B P I_{i t}$ captures one of the banking profitability indicators (ROA, ROE, NIM or PROFIT); $\varepsilon_{1 i t}, \varepsilon_{2 i t}, \varepsilon_{3 i t}$ are independently and identically distributed errors. The maximum lag order $k$ of the right-hand variables can be determined with the Akaike Information Criterion. The coefficients of interest, $\beta$, are representing the short-run Granger-causality, while coefficients, $\delta$, are examining the longrun Granger-causality between the variables. The long-run relationship can be estimated by panel fully modified ordinary least square or dynamic ordinary least square (Pedroni, 2000). However, Model 1 is meaningful only if all the variables, GRW, BSI, BPI, have the same order of integration and are co-integrated. Therefore, the tests for panel unit root and co-integration are necessary to proceed before the estimation of the model.

In the case of the mixed orders of integration, that is, the variables are both $I(0)$ and $I(1)$, panel autoregressive-distributed lag (PARDL) method is more appropriate. This approach can deal with the co-integration progress for a long-term connection, regardless of whether the covariates are $I(0), I(1)$, or a mix of both (Nkoro and Uko, 2016). Our model can be written as:
Banking profit, security and economic growth 


$$
\Delta y_{i t}=\varnothing_{i}\left(y_{i t-1}-\dot{\theta}_{i} X_{i t}\right)+\sum_{j=1}^{p-1} \lambda_{i j}^{*} \Delta y_{i t-1}+\sum_{j=0}^{q-1}{ }^{\prime} \delta_{i j}^{*} \Delta X_{i t-j}+\mu_{i}+\epsilon_{i t}
$$

where $i$ denotes the individual ASEAN members, $t$ denotes years over $1996-2017 ; \Delta$ is the first different filter; $y_{i t}$ and $X_{i t}$ are the vectors which each includes three variables GRW (capturing economic growth), BSI (capturing one of the banking profitability indicators ROA, ROE, NIM or PROFIT), and BPI (capturing one of the banking stability indicators ZSC, CRE, LIQ or STABILITY); $\mu_{i}$ denotes individual fixed effects; $\epsilon_{i t}$ is a vector of independently and identically distributed errors. The maximum lag order $p$ and $\mathrm{q}$ of the right-hand variables are determined by the Akaike Information Criterion. The coefficient of interest is the vector $\varnothing_{i}$, representing the long-run Granger-causality or error-correcting speed of adjustment, while the vector $\delta_{i j}^{\prime}$ captures the short-run Granger-causality. Another importance is the vector $\theta_{i}^{\prime}$, which contains the long-term relationship between the underlying variables.

Regarding Pesaran et al. (1999), we allow for the heterogeneous short-term dynamics but the homogeneous long-term connection between the variables across the ASEAN area when employing the PARDL. In other words, vectors $\varnothing_{i}$ and $\theta_{i}^{\prime}$ are homogeneous, while vector $\delta_{i j}^{\prime *}$ is heterogeneous across the countries. We assume that the ASEAN countries are homogeneous enough to have the same long-run interaction between banking and economic advancement. However, the short-run relationship should be different between the countries.

\section{Empirical results and discussion}

We will start by examining the panel cross-sectional independence. Under the Breusch and Pagan test, the panel cross-sectional dependence is confirmed. Thus, the second-generation test for panel unit root is utilized (Pesaran, 2007). For robustness, the test is done with various lags and different model specifications. The final interpretation is based on the majority of the results. At the level data, we have the combination of variables with different orders of integration in which ZSC, CRE, LIQ, STABILITY and NIM are $I(1)$, while the others are $I(0)$. Thus, the PARDL method should be employed. However, this model cannot run with $I(2)$ variables. In Table 2 , at the first-difference level, all variables are $I(0)$, except for STABILITY. Thus, for the validity of estimations, variable STABILITY is excluded.

Table 3 represents the estimations of both short- and long-run Granger-causality between the variables from Model 2. The detailed results are interpreted as follows, while Table 4 recaps the confirmed hypotheses on the short-run Granger-causality.

For the short-run Granger-causality, we observe both unidirectional and non-directional causalities between banking profitability and economic development. However, in most cases, the unidirectional causal effect of banking profitability on the growth is affirmed (BPI $\rightarrow$ GRW), while the non-directional one is occasionally presented (BPI $<\neq>$ GRW). By contrast, the short-term Granger-causality between banking security and growth expansion is unclear. In Table 4, half of the cases demonstrate the non-directional causality (BSI $<\neq>$ GRW), while the others show the mixed unidirectional causalities. The same argument is also given to short-run Granger-causality between banking earnings and banking security. The results vary with different measures for banking profit or security.

However, the long-term Granger-causality between the variables is strongly confirmed when the estimations of ECTs are mostly significant and reflect the expected negative sign.

The empirical evidence provides us with more insights into the interconnection between the variables. Only the short-term Granger-causal link from banking earnings to output growth is significantly clear, while the other cases are non-uniform. However, we recognize the significant long-run Granger causalities between all the variables because of the general 


\begin{tabular}{|c|c|c|c|c|c|c|c|c|}
\hline \multirow[b]{3}{*}{ Variable } & \multirow[b]{3}{*}{$\begin{array}{l}\text { Number of } \\
\text { lags }\end{array}$} & \multicolumn{6}{|c|}{$\begin{array}{l}\text { PESARAN'S panel unit root test results } \\
\text { Zt-bar statistical value }\end{array}$} & \multirow{3}{*}{$\begin{array}{r}\text { Banking profit, } \\
\text { security and } \\
\text { economic } \\
\text { growth }\end{array}$} \\
\hline & & \multicolumn{3}{|c|}{ Part 1: At level data } & \multicolumn{3}{|c|}{ Part 2: At first difference } & \\
\hline & & $\begin{array}{l}\text { Without } \\
\text { trend }\end{array}$ & $\begin{array}{l}\text { With } \\
\text { trend }\end{array}$ & Inference & $\begin{array}{l}\text { Without } \\
\text { trend }\end{array}$ & $\begin{array}{l}\text { With } \\
\text { trend }\end{array}$ & Inference & \\
\hline \multirow[t]{3}{*}{ ZSC } & 1 & $-2.175^{* *}$ & -0.853 & \multirow[t]{3}{*}{$I(1)$} & $-6.631^{* * *}$ & $-6.324^{* * *}$ & \multirow[t]{3}{*}{$I(0)$} & \\
\hline & 2 & -0.189 & 2.721 & & $-2.105 * *$ & $-2.329 * * *$ & & 257 \\
\hline & 3 & 0.371 & -0.850 & & 1.523 & 2.330 & & \\
\hline \multirow[t]{3}{*}{ CRE } & 1 & $-6.525 * * * *$ & $-3.200 * * * *$ & $I(1)$ & $-6.053 * * *$ & $-8.773^{* * * *}$ & \multirow[t]{3}{*}{$I(0)$} & \\
\hline & 2 & $-2.705^{* * *}$ & 0.216 & & $-1.566^{*}$ & $-1.412^{*}$ & & \\
\hline & 3 & 0.252 & 1.458 & & $-1.520^{*}$ & $-3.422^{* * *}$ & & \\
\hline \multirow[t]{3}{*}{ LIQ } & 1 & -0.635 & -0.865 & $I(1)$ & $-5.103 * * *$ & $-3.943^{* * *}$ & \multirow{3}{*}{$I(0)$} & \\
\hline & 2 & -0.079 & 1.360 & & $-1.327^{*}$ & -0.268 & & \\
\hline & 3 & 0.088 & -0.871 & & $-2.432 * * *$ & 0.866 & & \\
\hline \multirow[t]{3}{*}{ STABILITY } & 1 & -0.400 & 1.119 & $I(1)$ & $-4.486 * * *$ & $-4.412^{* * *}$ & \multirow[t]{3}{*}{$I(1)$} & \\
\hline & 2 & 1.001 & 3.032 & & 0.502 & -1.100 & & \\
\hline & 3 & 0.972 & 2.198 & & 4.172 & 1.657 & & \\
\hline \multirow[t]{3}{*}{ ROA } & 1 & $-4.005^{* * *}$ & $-2.710 * * *$ & $I(0)$ & - & - & & \\
\hline & 2 & $-2.412^{* * * *}$ & $-1.316^{*}$ & & - & - & & \\
\hline & 3 & -0.990 & $-3.047^{* * * *}$ & & - & - & & \\
\hline \multirow{3}{*}{ ROE } & 1 & $-2.471 * * *$ & -0.962 & $I(0)$ & - & - & & \\
\hline & 2 & $-2.009 * *$ & -0.294 & & - & - & & \\
\hline & 3 & $-1.851^{* *}$ & $-3.169 * * *$ & & - & - & & \\
\hline \multirow[t]{3}{*}{ NIM } & 1 & $-1.679 * *$ & -0.991 & $I(1)$ & $-7.331 * * *$ & $-6.522^{* * *}$ & \multirow[t]{9}{*}{$\mathrm{I}(0)$} & \\
\hline & 2 & $-3.648 * * *$ & $-1.841 * *$ & & $-4.159 * * *$ & $-2.729 * * *$ & & \\
\hline & 3 & 2.257 & 2.906 & & -0.687 & -0.793 & & \\
\hline \multirow[t]{3}{*}{ PROFIT } & 1 & $-4.354 * * *$ & $-3.486^{* * * *}$ & $I(0)$ & - & - & & \\
\hline & 2 & $-1.878 * *$ & $-1.483^{*}$ & & - & - & & \\
\hline & 3 & $-1.877^{* *}$ & -0.960 & & - & - & & \\
\hline \multirow[t]{3}{*}{ GRW } & 1 & $-2.357 * * *$ & $-3.932 * * *$ & $I(0)$ & - & - & & \\
\hline & 2 & $-1.859 * *$ & $-2.533 * * *$ & & - & - & & \\
\hline & 3 & 0.576 & 0.696 & & - & - & & \\
\hline \multicolumn{8}{|c|}{$\begin{array}{l}\text { Note(s) 1: The null hypothesis of all tests is of panel unit root. } 2: I(0) \text { stands for the integration of zero-order, } \\
\text { while } I(1) \text { as the integration of order one. } 3: * * *, * * \text { and * corresponding to } 1,5 \text { and } 10 \% \text { significance levels, } \\
\text { respectively } \\
\text { Source(s): Author's calculation }\end{array}$} & $\begin{array}{l}\text { Table } 2 . \\
\text { Panel unit root test } \\
\text { results under the } \\
\text { second-generation test }\end{array}$ \\
\hline
\end{tabular}

significance of ECTs coefficients. In other words, in the $\Delta \mathrm{GRW}$ equation, both banking stability and profit Granger - cause economic growth in the long run. The same conclusion is also drawn to banking earnings and banking security when they are dependent variables.

The negative sign of ECTs coefficients in the $\Delta \mathrm{GRW}$ equations implies the change in the level of economic growth ( $\Delta \mathrm{GRW})$, in fact, responds to any earlier short-run disequilibrium. In other words, the effect of shocks to BPI or BSI on GRW will be absolutely adjusted in the long run. The same argument is drawn when we consider $\Delta \mathrm{BPI}$ and $\Delta \mathrm{BSI}$ as dependent variables. However, in the case of $\Delta \mathrm{GRW}$ as the dependent variable, the speed of adjustment is the largest, while it is the smallest when $\Delta \mathrm{BSI}$ is the dependent variable. The empirical results indicate that the banking safeness will correct its previous period disequilibrium at a speed of convergence of about $20-30 \%$ per annum when ZSC and LIQ are proxies, while only $3-7 \%$ when CRE as the proxy. This implies that recovering the banking stability to its long-run equilibrium is more difficult and takes more time compared to the banking profit or economic development.

Another importance is the estimated coefficients of $\theta_{i}^{\prime}$, representing the long-run relationship between the variables. Table 5 strongly indicates the long-term impacts of 
JED
22,2

258

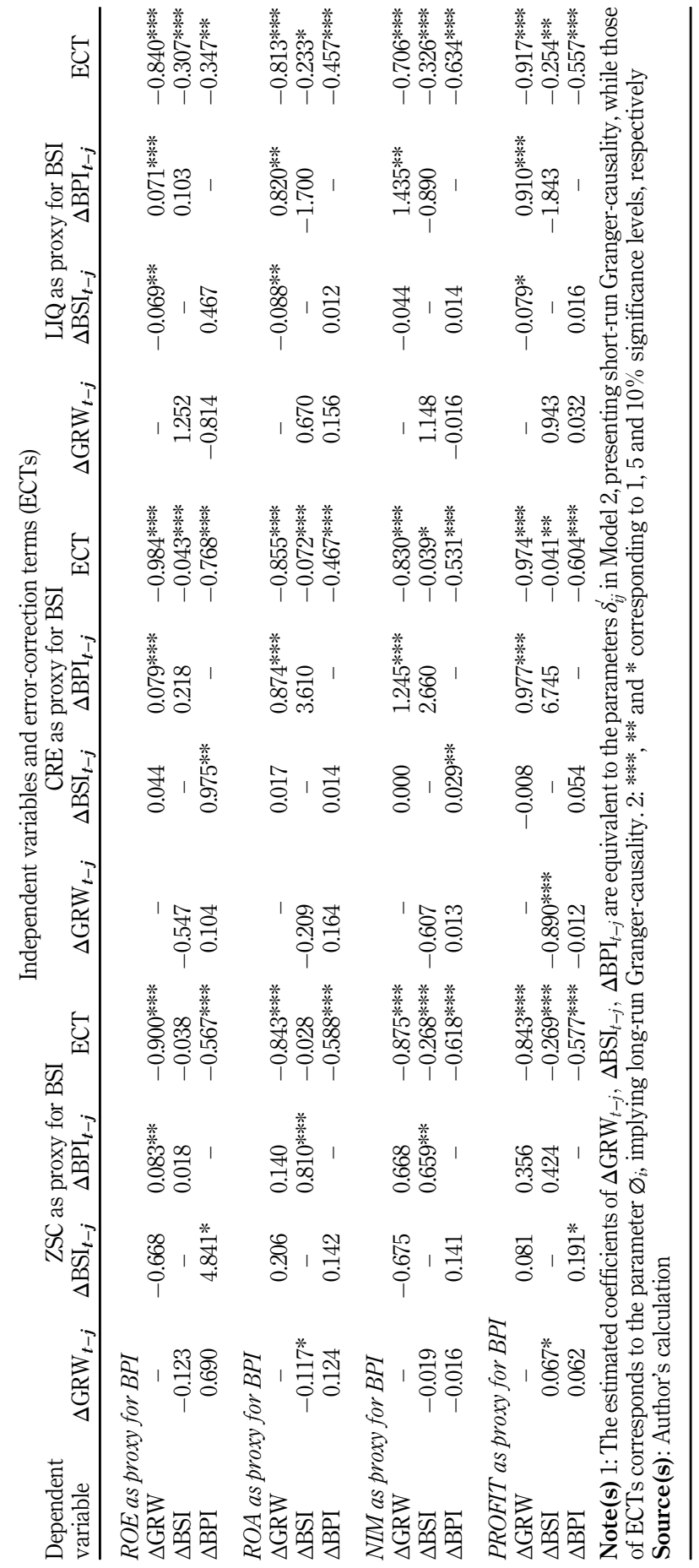

Table 3.

Results of panel

Granger-causality estimations from Model 2 


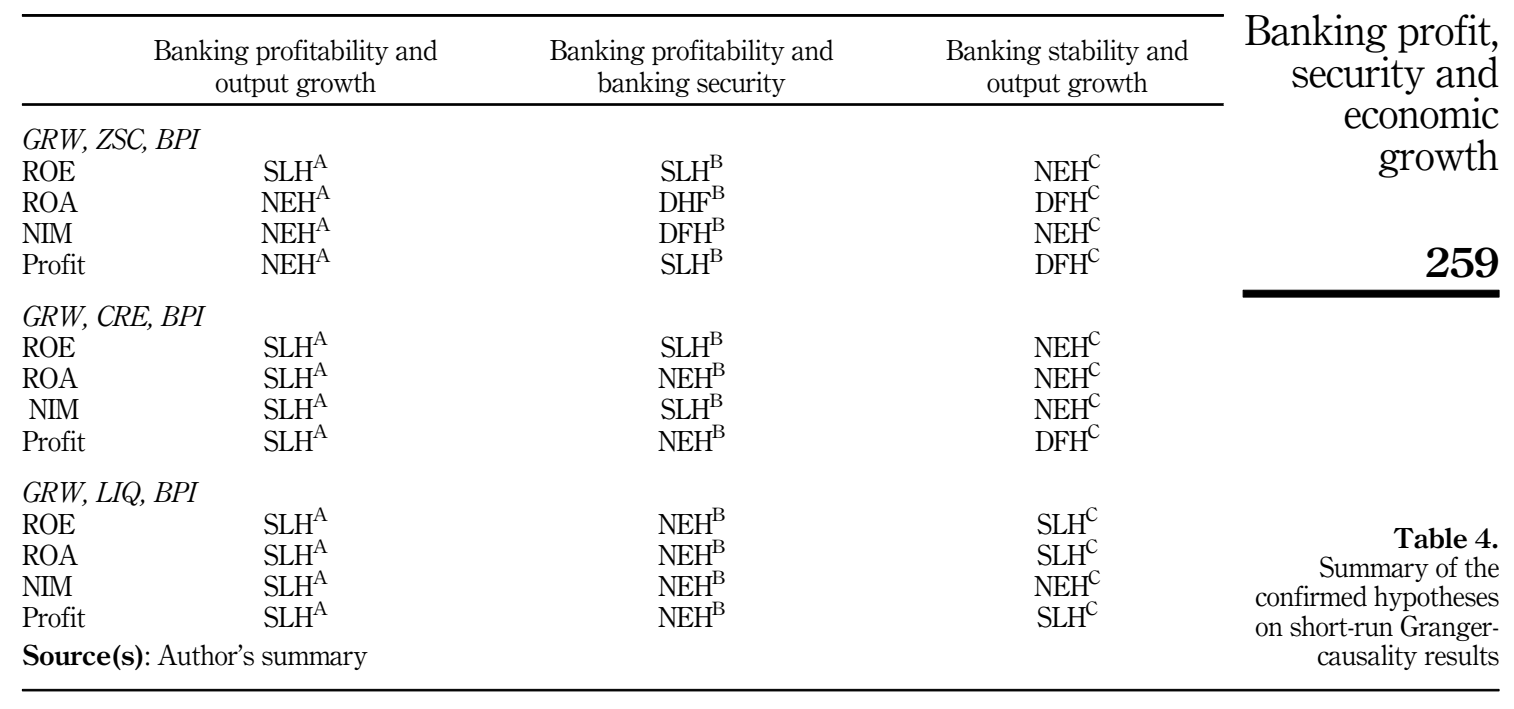

\begin{tabular}{|c|c|c|c|c|c|c|c|c|}
\hline \multirow{2}{*}{$\begin{array}{l}\text { Independent } \\
\text { variable Dependent } \\
\text { variable }\end{array}$} & \multicolumn{3}{|c|}{ Banking stability indicator (BSI) } & \multicolumn{4}{|c|}{ Banking profitability indicator (BPI) } & \\
\hline & ZSC & CRE & LIQ & ROE & $\mathrm{ROA}$ & NIM & PROFIT & \\
\hline GRW & $-0.111^{* *}$ & - & - & $0.068^{* * * *}$ & - & - & - & \\
\hline GRW & $-0.170 * * *$ & - & _- & - & $1.029 * * *$ & - & _- & \\
\hline GRW & $-0.188^{* * * *}$ & - & - & - & - & $0.650 * * * *$ & - & \\
\hline GRW & $-0.144^{* * *}$ & - & - & - & - & - & $1.586^{* * * *}$ & \\
\hline GRW & - & -0.002 & - & 0.0182 & - & - & - & \\
\hline GRW & - & -0.001 & - & - & $0.387 * * *$ & - & - & \\
\hline GRW & - & -0.001 & - & - & - & -0.130 & - & \\
\hline GRW & - & -0.002 & - & - & - & - & $1.088^{* * * *}$ & \\
\hline GRW & - & - & $0.035 * *$ & $0.043 * * *$ & - & - & - & \\
\hline GRW & - & - & $0.052 * * *$ & - & $0.491 * * *$ & - & - & \\
\hline GRW & - & - & $0.059 * * *$ & - & - & $-0.476^{* * *}$ & - & Table 5 \\
\hline GRW & - & - & $0.032^{* *}$ & - & - & - & $1.146^{* * * *}$ & The long-run \\
\hline \multicolumn{9}{|c|}{$\begin{array}{l}\text { Note(s): } * * *, * * * \text { corresponding to } 1 \%, 5 \text { and } 10 \% \text { significance levels respectively } \\
\text { Source(s): Author's calculation }\end{array}$} \\
\hline
\end{tabular}

banking security and earnings on economic enhancement. Increased banking profitability causes higher economic growth. The results are consistent with Miralles-Quiros et al. (2018). By contrast, increased banking security has no uniform impact, relying on specific banking security indicators.

Particularly, the improved ZSC decreases economic expansion, while higher LIQ has the reverse effect. This can be explained that the banking $z$-score can be partly increased by the higher ratio of shareholder's equity over total assets [1]. However, the improved capital capacity could be a very costly procedure and this can deteriorate the banking earnings (Van Dang, 2019). In some circumstances, improving regulated capital qualification might stimulate banks to get more involved in value-deteriorating activities (Jacques and Nigro, 1997). 
JED

22,2

\section{Concluding remarks and policy implications}

The research pursues to assess the interaction between banking earnings, banking safeness and output growth across the ASEAN region, employing panel annual data over 1996-2017. We expect to deploy four measures for each banking stability and banking profitability assessment. However, due to the validity of panel autoregression distributed lag analysis, we finally use three measurements for banking safeness, but four ones for banking profitability.

From our estimation, the long-term impacts of banking well-being and banking stability on economic growth are strongly affirmed. However, while the increased banking profitability, on average, leads to higher economic development, the increased banking stability may have reverse effects in some circumstances.

We proceed with further research by examining the short- and long-term Grangercausality amongst the variables. Generally, there is no evidence for the uniform short-run Granger relation between banking profitability and stability or banking stability and economic growth, except for banking profitability and economic growth. Nevertheless, we conclude the uniform long-run Granger causality between all the variables. This means that any variable is strongly Granger-caused by the other two variables in the long run. Additionally, the speed of adjustment of the banking stability to its short-run disequilibrium is comparably small to those of banking profit and economic development, implying the convergence of the banking stability to its long-run equilibrium takes more time and is more difficult.

Thus, the questions remain how one government should affect banking stability and profitability to achieve a higher economic achievement, given their significant long-run Granger causality. Although the increased banking stability might deteriorate the economic growth in some cases, its absolute margin impact magnitude is relatively much lower than that of the higher banking profitability (Table 5). Thus, improving the banking well-being and safeness capacity simultaneously might have net positive effects on the economic growth. Contrarily, higher banking earnings without the corresponding higher soundness can harm growth enhancement in the short-run and much more in the long run because of potential doubtful loans. This is because the severe impact of reduced banking soundness can last long due to its narrow speed of convergence to the long-run equilibrium. Hence, national governments should focus on creating a convenient banking market, which can continuously maintain the increased banking profitability and safeness obligations simultaneously.

This research is restricted to some unavailable data and limited measurements of both banking profitability and banking stability as well. This may cause us to draw a less convenient picture of the interaction within a tri-cycle analysis of banking profitability, banking stability and economic performance. Additionally, further inclusion of other macroeconomic variables, or other banking development dimensions, or non-banking indicators can be further considered to obtain a better interaction amongst the variables.

\section{Note}

1. It is calculated as follows: $z_{i t}=\frac{\mathrm{ROA}_{i t}+(\mathrm{EQ} / \mathrm{TA})_{i t}}{\delta_{\mathrm{ROA}}}$, where ROA is the returns on assets; EQ/TA illustrates the ratio of equity to asset; $\delta_{\mathrm{ROA}}^{\delta_{\mathrm{ROA}}}$ represents the standard deviation of ROA. The higher the $z$-score, the more stable the banking sector.

\section{References}

Abel, S. and Le Roux, P. (2016), "Determinants of banking sector profitability in Zimbabwe", International Journal of Economics and Financial Issues, Vol. 6 No. 3, pp. 845-854.

Acaravci, S.K. and Çalim, A.E. (2013), "Turkish banking sector's profitability factors", International Journal of Economics and Financial Issues, Vol. 3 No. 1, pp. 27-41. 
Alshubiri, F.N. (2017), "Determinants of financial stability: an empirical study of commercial banks listed in Muscat Security Market”, Journal of Business and Retail Management Research, Vol. 11 No. 4, pp. 192-200.

Anthony, O. (2012), "Bank savings and bank credits in Nigeria: determinants and impact on economic growth", International Journal of Economics Financial Issues, Vol. 2 No. 3, pp. 357-372.

Banna, H., Shah, S.K.B., Noman, A.H.M., Ahmad, R. and Masud, M.M. (2019), "Determinants of sinoASEAN banking efficiency: how do countries differ?”, Economies, Vol. 7 No. 1, pp. 1-23.

Bolt, W., De Haan, L., Hoeberichts, M., Van Oordt, M.R. and Swank, J. (2012), "Bank profitability during recessions", Journal of Banking and Finance, Vol. 36 No. 9, pp. 2552-2564.

Chang, T. (2002), "Financial development and economic growth in Mainland China: a note on testing demand-following or supply-leading hypothesis", Applied Economics Letters, Vol. 9 No. 13, pp. 869-873.

Daly, S. and Frikha, M. (2016), "Banks and economic growth in developing countries: what about Islamic banks?”, Cogent Economics Finance, Vol. 4 No. 1, p. 1168728.

Dell'ariccia, G., Detragiache, E. and Rajan, R. (2008), "The real effect of banking crises", Journal of Financial Intermediation, Vol. 17 No. 1, pp. 89-112.

Fu, X.M., Lin, Y.R. and Molyneux, P. (2014), "Bank competition and financial stability in Asia Pacific", Journal of Banking and Finance, Vol. 38, pp. 64-77.

Habibullah, M.S. and Eng, Y.-K. (2006), "Does financial development cause economic growth? A panel data dynamic analysis for the Asian developing countries", Journal of the Asia Pacific Economy, Vol. 11 No. 4, pp. 377-393.

Hammond, B. (1991), Banks and Politics in America from the Revolution to the Civil War, Princeton University Press, Princeton, NJ.

Hicks, J. (1969), A Theory of Economic History, Oxford University Press, Oxford.

Hoggarth, G., Reis, R. and Saporta, V. (2002), "Costs of banking system instability: some empirical evidence", Journal of Banking and Finance, Vol. 26 No. 5, pp. 825-855.

Jacques, K. and Nigro, P. (1997), "Risk-based capital, portfolio risk, and bank capital: a simultaneous equations approach", Journal of Economics Business, Vol. 49 No. 6, pp. 533-547.

Jayakumar, M., Pradhan, R.P., Dash, S., Maradana, R.P. and Gaurav, K. (2018), "Banking competition, banking stability, and economic growth: are feedback effects at work?”, Journal of Economics Business, Vol. 96, pp. 15-41.

Jokipii, T. and Monnin, P. (2013), "The impact of banking sector stability on the real economy", Journal of International Money and Finance, Vol. 32, pp. 1-16.

Khan, H.H., Ahmad, R.B. and Chan, S.G. (2018), "Market structure, bank conduct and bank performance: evidence from ASEAN", Journal of Policy Modeling, Vol. 40 No. 5, pp. 934-958.

Knezevic, A. and Dobromirov, D. (2016), "The determinants of Serbian banking industry profitability", Economic Research-Ekonomska Istraživanja, Vol. 29 No. 1, pp. 459-474.

Kyophilavong, P., Uddin, G.S. and Shahbaz, M. (2016), "The nexus between financial development and economic growth in Lao PDR", Global Business Review, Vol. 17 No. 2, pp. 303-317.

Lewis, W.A. (1955), The Theory of Economic Growth, Routledge, Abingdon-on-Thames.

Miralles-Quiros, M.D.M., Miralles-Quiros, J.L. and Daza-Izquierdo, J. (2018), "Growth, profits and foreign ownership in the Brazilian banking industry", Applied Economics, Vol. 50 No. 51, pp. 5483-5494.

Motelle, I.S. and Biekpe, N. (2014), "Financial intermediation spread and stability of the banking system in the Southern Africa Customs Union”, Managerial Finance, Vol. 40 No. 3, pp. 276-299.

Nkoro, E. and Uko, A.K. (2016), "Autoregressive Distributed Lag (ARDL) cointegration technique: application and interpretation", Journal of Statistical and Econometric Methods, Vol. 5 No. 4, pp. 63-91. 
JED

22,2

262

Nucu, A.E.A. and Anton, S.G. (2019), "Competition-Stability in the banking sector and economic growth in Central and Eastern European countries", European Union Financial Regulation and Administrative Area, Alexandru Ioan Cuza University of Iasi, Erasmus+Programme.

Oktaviyanti, D. and Purnawan, M.E. (2019), "The behaviour of banking financial stability in ASEAN5", Economic Papers, Vol. 38 No. 4, pp. 329-344.

Patrick, H.T. (1966), "Financial development and economic growth in underdeveloped countries", Economic Development Cultural Change, Vol. 14 No. 2, pp. 174-189.

Pedro, C.P., Ramalho, J.J. and Da Silva, J.V. (2018), "The main determinants of banking crises in OECD countries", Review of World Economics, Vol. 154 No. 1, pp. 203-227.

Pedroni, P. (2000), "Fully modified OLS for heterogeneous cointegrated panels", Advances in Econometrics, Vol. 15, pp. 93-130.

Pesaran, M.H. (2007), "A simple panel unit root test in the presence of cross-section dependence", Journal of Applied Econometrics, Vol. 22 No. 2, pp. 265-312.

Pesaran, M.H., Shin, Y. and Smith, R.P. (1999), "Pooled mean group estimation of dynamic heterogeneous panels", Journal of the American Statistical Association, Vol. 94 No. 446, pp. $621-634$.

Pradhan, R.P., Arvin, M.B., Hall, J.H. and Bahmani, S. (2014), "Causal nexus between economic growth, banking sector development, stock market development, and other macroeconomic variables: the case of ASEAN countries", Review of Financial Economics, Vol. 23 No. 4, pp. 155-173.

Pradhan, R.P., Arvin, M.B., Bahmani, S., Hall, J.H. and Norman, N.R. (2017), "Finance and growth: evidence from the ARF countries", The Quarterly Review of Economics and Finance, Vol. 66, pp. 136-148.

Robinson, J. (1952), The Generalization of the General Theory in the Rate of Interest and Other Essays, MacMillan, London.

Ryoo, S. (2013), "Bank profitability, leverage and financial instability: a Minsky-Harrod model", Cambridge Journal of Economics, Vol. 37 No. 5, pp. 1127-1160.

Schumpeter, J.A. (1982), The Theory of Economic Development: An Inquiry into Profits, Capital, Credit, Interest, and the Business Cycle (1912/1934), Transaction Publishers, Piscataway, NJ.

Tagkalakis, A.O. (2014), "Financial stability indicators and public debt developments", The Quarterly Review of Economics and Finance, Vol. 54 No. 2, pp. 158-179.

Tan, Y. (2016), "The impacts of risk and competition on bank profitability in China", Journal of International Financial Markets, Institutions and Money, Vol. 40, pp. 85-110.

Trabelsi, M.A. and Trad, N. (2017), "Profitability and risk in interest-free banking industries: a dynamic panel data analysis", International Journal of Islamic and Middle Eastern Finance and Management, Vol. 10 No. 4, pp. 454-469.

Van Dang, D. (2019), "Should Vietnamese banks need more equity? Evidence on risk-return trade-off in dynamic models of banking", Journal of Risk and Financial Management, Vol. 12 No. 2, p. 84.

Wang, J. and Wang, J. (2015), "Forecasting stock market indexes using principle component analysis and stochastic time effective neural networks", Neurocomputing, Vol. 156, pp. 68-78.

Wulandari, Y. and Kusairi, S. (2017), "The impact of macroeconomic and internal factors on banking distress", International Journal of Economics and Financial Issues, Vol. 7 No. 3, pp. 429-436. 


\section{Appendix}

We create composite indicators for banking profit (variable PROFIT) and banking safeness (variable STABILITY), employing principal component analysis (PCA). We follow three main steps: firstly, obtaining an input matrix for principal components, that are normalized using the min-max approach. Secondly, eigenvalues, factor loadings and principle components are gained. Lastly, the composite indexes are created for every nation each year. The approach is introduced and employed in various previous studies (Wang and Wang, 2015). The results are shown below.
Banking profit, security and economic growth

263

For composite index of banking earnings (PROFIT)

\begin{tabular}{lccc} 
Part A: Eigen analysis of correlation matrix & & \\
PCs & Eigen value & Proportion & Cumulative \\
1 & 1.637 & 0.546 & 0.546 \\
2 & 0.923 & 0.308 & 0.854 \\
3 & 0.439 & 0.146 & 1.000 \\
\multicolumn{2}{l}{ Part B: Eigen vectors (Component loadings) } & & \\
Variables & PC1 & PC2 & PC3 \\
ROA & 0.6795 & -0.1254 & -0.7229 \\
ROE & 0.6398 & -0.3810 & 0.6674 \\
NIM & 0.3591 & 0.9160 & 0.1787 \\
\hline
\end{tabular}

For composite index of banking safeness (STABILITY)

Part A: Eigen analysis of correlation matrix

\begin{tabular}{|c|c|c|c|}
\hline PCs & Eigen value & Proportion & Cumulativ \\
\hline 1 & 1.293 & 0.431 & 0.431 \\
\hline 2 & 0.947 & 0.316 & 0.747 \\
\hline 3 & 0.760 & 0.253 & 1.000 \\
\hline \multicolumn{4}{|c|}{ Part B: Eigen vectors (Component loadings) } \\
\hline Variables & PC1 & $\mathrm{PC} 2$ & PC3 \\
\hline CRE & 0.4006 & 0.9084 & 0.1197 \\
\hline $\mathrm{ZSC}$ & 0.6345 & -0.3693 & 0.6790 \\
\hline LIQ & -0.6610 & 0.1960 & 0.7243 \\
\hline
\end{tabular}

Note(s): $\mathrm{PCs}$ indicate principal components; ROA is the returns on assets; ROE is the returns on equity; NIM is net interest margin; ZSC is banking $z$-score; $\mathrm{CRE}$ is private credit by deposit money banks; LIQ is bank liquid assets to deposits and short-term funding

Source(s): Author's calculation

Table A1.

Calculating the composite indexes of banking earnings and banking security 
JED
22,2

\begin{tabular}{lccccccccr}
\hline Variables & ZSC & \multicolumn{1}{c}{ CRE } & LIQ & STABILITY & ROA & ROE & NIM & PROFIT & GRW \\
\hline Observation & 187 & 195 & 191 & \multicolumn{1}{c}{186} & \multicolumn{1}{c}{188} & \multicolumn{1}{c}{188} & \multicolumn{1}{c}{190} & \multicolumn{1}{c}{187} & \multicolumn{1}{c}{198} \\
Minimum & 0.109 & \multicolumn{1}{c}{197.939} & 6.036 & -4.277 & -29.117 & -211.443 & 0.069 & -9.184 & -14.351 \\
Mean & 11.550 & 138.563 & 35.595 & 0.010 & 0.778 & 9.197 & 3.787 & 0.006 & 3.727 \\
Median & 11.509 & 88.127 & 30.959 & 0.040 & 1.088 & 11.849 & 3.376 & 0.066 & 4.296 \\
Maximum & 34.267 & 878.839 & 150 & 2.370 & 5.763 & 70.097 & 11.020 & 3.832 & 12.788 \\
Standard dev & 7.615 & 167.044 & 21.671 & 1.142 & 2.704 & 22.970 & 2.012 & 1.283 & 3.931 \\
Skewness & 0.546 & 2.789 & 1.885 & -0.629 & -8.062 & -6.274 & 0.6015 & -3.886 & -0.776 \\
Kurtosis & 2.450 & 9.879 & 8.409 & 3.973 & 84.446 & 54.106 & 3.013 & 26.656 & 5.735
\end{tabular}
$\begin{array}{ll}\text { Table A2. } & \text { deposits and short-term funding; STABILITY is the composite index; ROA is return on assets; ROE is retur } \\ \text { Descriptive statistics of } & \text { equity; NIM is net interest margin; PROFIT is composite indicator and GRW is per capita GDP growth }\end{array}$

Note(s): ZSC is banking system Z-scores; CRE is private credit by domestic deposit; LIQ is bank liquid assets to variables

Source(s): Author's calculation

\section{Corresponding author}

Minh Phu Pham can be contacted at: phuminhvnese@gmail.com

For instructions on how to order reprints of this article, please visit our website:

www.emeraldgrouppublishing.com/licensing/reprints.htm

Or contact us for further details: permissions@emeraldinsight.com 